\section{Salinity Tolerance of Ryegrass Turf Cultivars}

\author{
Kenneth B. Marcum ${ }^{1}$ \\ Centre for Urban Greenery and Ecology, National Parks Board, 1 Cluny \\ Road, Singapore 259569
}

\author{
Mohammad Pessarakli \\ School of Plant Sciences, University of Arizona, Tucson, AZ 85721
}

Additional index words. Lolium spp., turfgrass, salinity tolerance

\begin{abstract}
Relative salinity tolerance of 32 perennial (Lolium perenne L.) and three intermediate (Lolium $\times$ hybridum Hausskn.) ryegrass turf cultivars was determined by measuring turf leaf clipping dry weight, root weight, rooting depth, and percent green leaf canopy area relative to control (non-salinized) plants. After gradual acclimation, grasses were exposed to moderate salinity stress $\left(6 \mathrm{dS} \cdot \mathrm{m}^{-1}\right)$ for 6 weeks through solution culture in a controlled environment greenhouse. Shoot parameters were highly correlated, being mutually effective predictors of salinity tolerance. After 6 weeks of salinity stress, percent green leaf canopy area (GL) was correlated with relative (to control) final week leaf clipping weight $\left(L W_{R E L}\right)(r=0.90)$ and with linear slope of decline of weekly leaf clipping weight over the 6-week exposure to salinity ( $\left.L W_{\text {SLOPE }}\right)(r=0.66)$. Rooting parameters root dry weight (RW) and rooting depth (RD), although significantly correlated with all shoot parameters, were only moderately effective in predicting relative salinity tolerance. 'Paragon' was the most salt-tolerant as indicated by all parameters. Other salt-tolerant cultivars included Divine and Williamsburg. Intermediate ryegrass cultivars (Froghair, Midway, and Transist) were invariably found within the most salt-sensitive category for all parameters.
\end{abstract}

Increasing population growth in large urban centers is resulting in critical potable water shortages (Anderson et al., 2005; Kjelgren et al., 2000), a trend progressively worsening as a result of droughts related to global climate change (Barnett et al., 2005; Pearman et al., 2003). Demand on limited potable water resources is resulting in government-mandated water use restrictions, which limit use of potable water while requiring use of reclaimed or other secondary saline water sources for irrigation of turfgrass landscapes (Arizona Department of Water Resources, 2003; California State Water Resources Control Board, 2006; Council of Australian Governments, 2004; Florida Department of Environmental Protection, 2006); therefore, the need for salt-tolerant turfgrasses is increasing (Harivandi et al., 2008).

Ryegrasses are among the most widely used $\mathrm{C}_{3}$ turfgrasses in cool regions as well as the most commonly used species for winter overseeding of dormant $\mathrm{C}_{4}$ turf in warm regions (Christians, 2007; Duble, 1996). Ryegrasses generally used for turf are of three species: perennial (Lolium perenne), annual or Italian (Lolium multiflorum Lam.), and intermediate (Lolium $\times$ hybridum), an interspecific hybrid of the two. Of these, perennial and intermediate ryegrasses are generally used in modern turf landscapes as a result of their higher quality (Turgeon, 2005).

Received for publication 5 Aug. 2010. Accepted for publication 20 Sept. 2010.

${ }^{1}$ To whom reprint requests should be addressed; e-mail kenneth_marcum@nparks.gov.sg.
Perennial ryegrass has been ranked moderate in salinity tolerance, tolerating soil $\mathrm{ECe}$ (saturated paste extract) ranging from 4 to 8 $\mathrm{dS} \cdot \mathrm{m}^{-1}$ (Harivandi et al., 1992) with annual and intermediate ryegrasses ranked more salt-sensitive, tolerating soil ECe from 3 to $5 \mathrm{dS} \cdot \mathrm{m}^{-1}$ (Marcum, 2006). In a field trial in which turfgrasses were grown on a saline soil with average ECe $11 \mathrm{dS} \cdot \mathrm{m}^{-1}$, six perennial ryegrass accessions or cultivars tended (no statistical analysis was done) to maintain equivalent visual quality to 11 kentucky bluegrass ( $\mathrm{Poa}$ pratensis L.) cultivars and better quality than six red fescue (Festuca rubra L.) and three colonial bentgrass (Agrostis capillaris L.) cultivars (Gibeault et al., 1977). In a pot study comparing different $\mathrm{C}_{3}$ turf species irrigated periodically with either fresh or saline water (soil salinity not controlled), salinity tolerance, again determined as visual quality, decreased in the order creeping bentgrass (Agrostis stolonifera L.) cv. Seaside > perennial ryegrass cvs. Common and NK $200=$ kentucky bluegrass cvs. Park, Pennstar, and Nugget $>$ rough bluegrass (Poa trivialis L.) accession (Greub et al., 1985). Salinity tolerance, measured as relative (to control) shoot dry weight reduction in plants exposed to $300 \mathrm{~mm} \mathrm{NaCl}$ for 2 weeks, was greater in perennial ryegrasses than in an accession of annual ryegrass; however, there was no significant difference among three perennial ryegrass cultivars tested (Marcar, 1987). Little information is available regarding the range in salinity tolerance present among ryegrass turf cultivars. The goal of this study was to determine the degree and range of salinity tolerance present among a broad selection of modern ryegrass turf cultivars.
Thirty-two perennial and three intermediate ryegrass cultivars (Table 1) were seeded at a rate of $35 \mathrm{~g} \cdot \mathrm{m}^{-2}$ into 7 -cm-diameter $\times$ 8 -cm-deep pots with coarse plastic screen bottoms filled with coarse, acid-washed silica sand. Cultivars were chosen based on extent of use by the turfgrass industry. Grasses were germinated under mist and then transferred to constantly aerated solution culture tanks using a previously developed solution culture protocol (Marcum and Pessarakli, 2006). Temperatures were maintained at 28 to $32^{\circ} \mathrm{C}$ day/20 to $24{ }^{\circ} \mathrm{C}$ night with maximum photosynthetically active radiation levels of $950 \mu \mathrm{mol} \cdot \mathrm{m}^{-2} \cdot \mathrm{s}^{-1}$. To minimize differential shading effects of greenhouse support beams during early morning and late afternoon, light levels were supplemented for $2 \mathrm{~h}$ daily: $1 \mathrm{~h}$ during early morning (immediately after sunrise) and $1 \mathrm{~h}$ during late afternoon (immediately before sunset) with high-pressure sodium lamps (1000 W; Energy Technics, York, PA).

Turfgrasses were established for 2 months before initiation of salinity treatments. Salinity levels were increased daily by $1 \mathrm{dS} \cdot \mathrm{m}^{-1}$ in treatment tanks (control tanks received no salt) using a 3:1 ratio by weight of $\mathrm{NaCl}: \mathrm{CaCl}_{2}$ salts until $6 \mathrm{dS} \cdot \mathrm{m}^{-1}$ was reached. Data collection began 1 week after reaching final treatment salinity levels. Grasses were held at $6 \mathrm{dS} \cdot \mathrm{m}^{-1}$ for 6 weeks, during which relative leaf clipping dry weight, calculated as (treatment leaf dry weight/control leaf dry weight $) \times 100$, and percent GL were recorded weekly. Solutions were monitored daily for salinity level using a Model 2052 conductivity meter with a platinum dip cell (VWR Scientific, Chicago, IL), adjusted when necessary, and changed every $10 \mathrm{~d}$ to ensure minimal changes in nutrient ion concentrations.

Grasses were clipped twice per week at 2-cm height. Biweekly clippings were dried at $60{ }^{\circ} \mathrm{C}$ and combined for weekly dry weight determination. RD, i.e., distance from the crown to the longest extending root, and RW were measured at the end of the experiment. To ensure uniform starting conditions, roots were clipped back to the bottoms of the pots at the beginning of the experiment.

The experimental design was a randomized complete block with six replications, each solution tank containing all 35 cultivars. Data were analyzed by analysis of variance using least significant difference separation of treatment means. Weekly relative leaf clipping dry weights were regressed against time to obtain the $\mathrm{LW}_{\mathrm{SLOPE}}$. GL and relative leaf clipping weight data were transformed by arcsine before analysis (Steel and Torrie, 1980) but are presented as percentages. Pearson product moment correlation coefficients were used to compare all variables. Data analysis was performed using SAS (Der and Everitt, 2001).

\section{Results and Discussion}

Plant tolerance to a given stress is the product of stress level and duration (Levitt, 
1980) with duration (exposure time) a more sensitive indicator for subtle differences in stress tolerance, particularly at the intraspecies or cultivar level (Chen et al., 1982). In this study, plants were held under a moderate stress level of $6 \mathrm{dS} \cdot \mathrm{m}^{-1}$, this reported to be a critical level of salinity tolerance for perennial ryegrass (Harivandi et al., 1992).

Because turfgrass is an aesthetic landscape plant, visual quality, indicated as percent GL, is of primary importance (Morris and Shearman, 1999). After 6 weeks exposure to $6 \mathrm{dS} \cdot \mathrm{m}^{-1}$, GL ranged from $67 \%$ to $0 \%$, indicating a broad range of salinity tolerance in ryegrasses (Table 1). 'Paragon' was significantly more salt-tolerant than other cultivars followed by 'Williamsburg' and 'Divine' in the second statistical group. Least salt-tolerant cultivars included all intermediate ryegrasses as well as perennial ryegrass cultivars Lowgrow II, Pace, Monterey, Linedrive, and Manhattan III. All intermediate ryegrasses had died after 3 weeks of salinity exposure, and perennial ryegrass cultivars LineDrive and Manhattan III died within 4 to 5 weeks of exposure.

Relative shoot dry weight, an indicator of plant vigor under stress relative to control conditions, is a commonly used indicator of salinity tolerance (Shannon, 1997; van Genuchten and Hoffman, 1984). After 6 weeks of exposure to $6 \mathrm{dS} \cdot \mathrm{m}^{-1}, \mathrm{LW}_{\mathrm{REL}}$ ranged from $61 \%$ to $0 \%$ (Table 1). 'Paragon' was again the most salt-tolerant cultivar followed by 'Divine' in the second and 'Jiffie', 'Express', 'Caddieshack', and 'Essence' in the third statistically significant group. Least salttolerant cultivars included all intermediate ryegrasses as well as nine perennial ryegrass cultivars.

Changes in relative shoot dry weight with level or time of exposure, indicated by slope, is also a commonly used salt tolerance indicator (Maas, 1990). LW SLOPE $_{\text {decreased }}$ linearly with time of exposure to salinity (Fig. 1). This indicates the glycophytic (low to moderately salt-tolerant) nature of ryegrasses in contrast to curvilinear growth response of halophytic (highly salt-tolerant) plants (Flowers, 1985). All shoot parameters were highly correlated (Table 2), indicating their mutual effectiveness in predicting salinity tolerance.

Root dry weight was highest in cvs. Paragon, Pinnacle, Spyglass, Superfly, Sunshine, and Top Gun and lowest in the three intermediate ryegrasses (Table 1). For RD, the highest significant group included 'Paragon' and the lowest group included all intermediate ryegrasses (Table 1). Both rooting parameters were significantly, although not highly correlated with shoot tolerance parameters (Table 2), thus only moderately effective in predicting salinity tolerance.

A wide range of salinity tolerance was found among 35 modern ryegrass turf cultivars, indicating the genetic potential for improvement in this genus. Shoot parameters GL, $\mathrm{LW}_{\mathrm{REL}}$, and $\mathrm{LW}_{\mathrm{SLOPE}}$ were highly correlated and equally effective in predicting

Table 1. Salinity tolerance parameters of 35 ryegrass (Lolium spp.) turf cultivars after 6 weeks of exposure to $6 \mathrm{dS} \cdot \mathrm{m}^{-1}$ root media salinity. ${ }^{2}$

\begin{tabular}{|c|c|c|c|c|c|}
\hline Cultivar & GL (\%) & $\mathrm{LW}_{\mathrm{REL}}(\%)$ & $\mathrm{LW}_{\text {SLOPE }}$ & RW (g) & $\mathrm{RD}(\mathrm{cm})$ \\
\hline $\begin{array}{l}\text { Paragon } \\
\end{array}$ & 67 & 61.4 & -0.99 & 1.50 & 8.1 \\
\hline Williamsburg & 37 & 22.9 & -1.89 & 1.25 & 5.9 \\
\hline Divine & 33 & 39.9 & -1.53 & 1.10 & 6.6 \\
\hline Jiffie & 23 & 28.5 & -1.79 & 0.91 & 0.7 \\
\hline Pinnacle & 20 & 17.6 & -2.05 & 1.36 & 4.0 \\
\hline Spyglass & 20 & 16.7 & -1.93 & 1.37 & 3.7 \\
\hline Express & 17 & 32.3 & -1.72 & 0.91 & 6.2 \\
\hline Caddieshack & 17 & 28.5 & -1.79 & 0.96 & 5.5 \\
\hline Essence & 17 & 25.8 & -1.84 & 1.01 & 0.5 \\
\hline Cutter & 17 & 23.3 & -1.80 & 1.07 & 3.7 \\
\hline Majesty & 17 & 21.8 & -1.96 & 1.26 & 1.3 \\
\hline Wilmington & 17 & 14.7 & -2.08 & 1.14 & 4.2 \\
\hline Achiever & 17 & 9.6 & -2.21 & 0.91 & 3.2 \\
\hline Gator II & 13 & 19.7 & -2.19 & 0.96 & 4.0 \\
\hline Legacy II & 13 & 13.2 & -2.02 & 1.03 & 5.6 \\
\hline BlackHawk & 13 & 5.8 & -2.24 & 0.61 & 4.6 \\
\hline Fiesta III & 10 & 19.7 & -2.01 & 0.99 & 0.8 \\
\hline Laredo & 10 & 17.5 & -2.16 & 0.92 & 5.5 \\
\hline Top Hat & 10 & 12.3 & -2.30 & 0.91 & 3.3 \\
\hline Superfly & 10 & 10.2 & -2.18 & 1.29 & 3.3 \\
\hline Ascend & 7 & 15.0 & -2.32 & 1.26 & 3.3 \\
\hline Premier III & 7 & 10.6 & -2.13 & 1.14 & 3.0 \\
\hline Calypso II & 7 & 8.0 & -2.33 & 0.92 & 6.6 \\
\hline Sunshine & 7 & 7.1 & -2.19 & 1.29 & 0.5 \\
\hline Peak & 7 & 6.3 & -2.29 & 1.07 & 5.8 \\
\hline Platinum & 7 & 5.2 & -2.38 & 1.06 & 7.8 \\
\hline Top Gun & 7 & 5.0 & -2.36 & 1.36 & 4.4 \\
\hline Lowgrow II & 3 & 9.0 & -2.46 & 0.79 & 0.3 \\
\hline Pace & 3 & 3.9 & -2.39 & 0.90 & 1.5 \\
\hline Monterey & 3 & 2.8 & -2.62 & 0.89 & 2.4 \\
\hline LineDrive & 0 & 0 & -3.13 & 1.01 & 6.0 \\
\hline Midway (hybridum) & 0 & 0 & -2.84 & 0.22 & 1.4 \\
\hline Manhattan III & 0 & 0 & -3.91 & 0.80 & 0.2 \\
\hline Transist (hybridum) & 0 & 0 & -4.63 & 0.26 & 0.1 \\
\hline Froghair (hybridum) & 0 & 0 & -4.89 & 0.10 & 0.1 \\
\hline $\mathrm{LSD}_{0.05}$ & 6 & 7.4 & & 0.21 & 1.8 \\
\hline
\end{tabular}

${ }^{2}$ Shoot parameters include percent green leaf canopy area (GL), final week relative leaf clipping dry weight (as percent of control) ( $\mathrm{LW}_{\mathrm{REL}}$ ), and linear slope of decline of weekly clipping dry weight over the 6 weeks of exposure to salinity $\left(\mathrm{LW}_{\mathrm{SLOPE}}\right)$. Rooting parameters are root dry weight $(\mathrm{RW})$ and rooting depth $(\mathrm{RD})$. Intermediate ryegrasses are designated as (hybridum). LSD $=$ least significant difference.

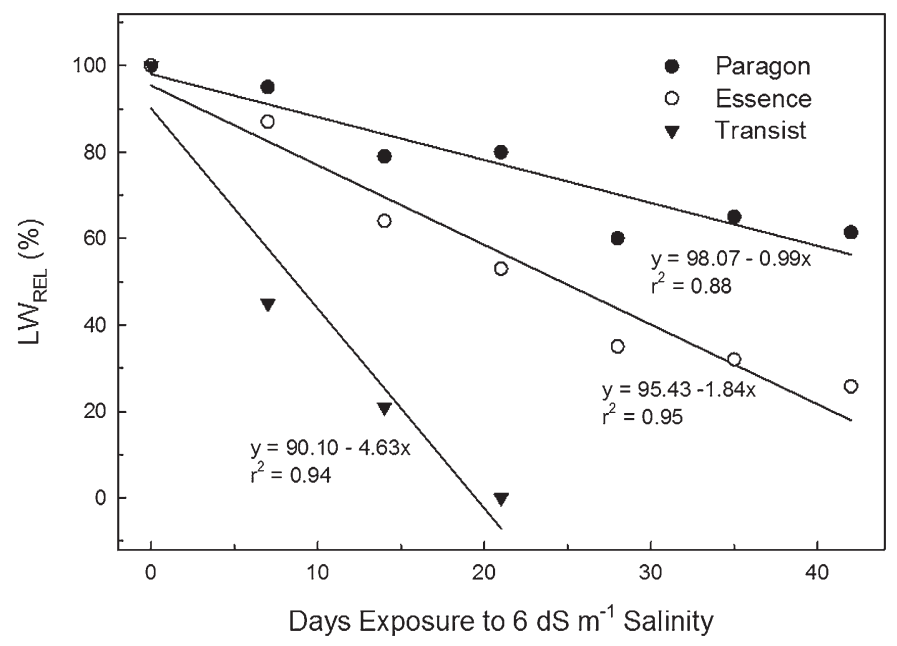

Fig. 1. Linear regressions of relative leaf clipping weight ( $\left(\mathrm{WW}_{\mathrm{REL}}\right)$ versus days exposure to salinity. Data means of six replications are indicated as points.

salinity tolerance, although root parameters RW and RD were less effective. Salt-tolerant cultivars included Paragon, Divine, and
Williamsburg. Intermediate ryegrasses were invariably the least salt-tolerant across all measurement parameters. 
Table 2. Pearson product moment correlation coefficients and associated probability levels for percent green leaf canopy area (GL), relative leaf clipping weight ( $\left.\mathrm{LW}_{\mathrm{REL}}\right)$, linear slope of decline of weekly clipping weight ( $\mathrm{LW}_{\mathrm{SLOPE}}$ ), root dry weight $(\mathrm{RW})$, and rooting depth (RD) after 6 weeks of exposure to $6 \mathrm{dS} \cdot \mathrm{m}^{-1}$ root media salinity.

\begin{tabular}{lllll}
\hline Variable & \multicolumn{1}{c}{$\mathrm{GL}$} & $\mathrm{LW}_{\text {REL }}$ & $\mathrm{LW}_{\text {SLOPE }}$ & $\mathrm{RW}$ \\
\hline $\mathrm{LW}_{\text {REL }}$ & 0.90 & & & \\
& 0.0001 & & & \\
$\mathrm{LW}_{\text {SLOPE }}$ & 0.66 & 0.71 & & \\
& 0.0001 & 0.0001 & & \\
$\mathrm{RW}$ & 0.52 & 0.48 & 0.73 & \\
& 0.001 & 0.004 & 0.0001 & \\
$\mathrm{RD}$ & 0.48 & 0.40 & 0.49 & 0.43 \\
& 0.004 & 0.018 & 0.003 & 0.011 \\
\hline
\end{tabular}

\section{Literature Cited}

Anderson, R.F., B. Rosenberg, and J. Sheahan. 2005. National city water survey 2005. U.S. Conf. Mayors Urban Water Council, Washington, DC. 15 Nov. 2010. <http://www.usmayors.org/ 74thWinterMeeting/NationalCityWaterSurvey 2005.pdf>.

Arizona Department of Water Resources. 2003. Third management plan: 2000-2010. 15 Nov. 2010. <http://www.azwater.gov/AzDWR/Water Management/AMAs/ThirdManagementPlan3. htm $>$.

Barnett, T.P., J.C. Adam, and D.P. Lettenmaier. 2005. Potential impacts of a warming climate on water availability in snow-dominated regions. Nature 438:303-309.

California State Water Resources Control Board. 2006. Porter-Cologne water quality control act, California Water Code, Section 13552-13577, 15 Nov. 2010. <http://www.waterboards.ca.gov/ laws_regulations/docs/portercologne.pdf $>$.

Chen, H.H., Z.Y. Shen, and P.H. Li. 1982. Adaptability of crop plants to high temperature stress. Crop Sci. 22:719-725.
Christians, N. 2007. Fundamentals of turfgrass management. 3rd Ed. Wiley, New York, NY.

Council of Australian Governments. 2004. National water initiative. Council of Australian Governments, 25 June, Canberra, ACT. 15 Nov. 2010. $<$ http://www.coag.gov.au/coag_meeting_outcomes/ 2004-06-25/docs/iga_national_water_initiative. pdf $>$.

Der, G. and B.S. Everitt. 2001. A handbook of statistical analyses using SAS. 2nd Ed. CRC Press, New York, NY.

Duble, R.L. 1996. Turfgrasses: Their management and use in the southern zone. Texas A\&M Univ. Press, College Station, TX.

Florida Department of Environmental Protection. 2006. Applicable rules for reuse projects. Chap. 62-610, Reuse of reclaimed water and land application. Florida Dept. Environmental Protection, Tallahassee, FL. 15 Nov. 2010. <http:// www.dep.state.fl.us/water/reuse/>.

Flowers, T.J. 1985. Physiology of halophytes. Plant Soil 89:41-56.

Gibeault, V.A., D. Hanson, D. Lancaster, and E. Johnson. 1977. Final research report: Cool season variety study in high salt location. Calif. Turfgrass Culture 27:11-12.

Greub, L.J., P.N. Drolsom, and D.A. Rohweder. 1985. Salt tolerance of grasses and legumes for roadside use. Agron. J. 77:76-80.

Harivandi, M.A., J.D. Butler, and L. Wu. 1992. Salinity and turfgrass culture, p. 207-229. In: Waddington, D.V., R.N. Carrow, and R.C Shearman (eds.). Turfgrass-Agron Monogr. 32. Amer. Soc. Agron., Madison, WI.

Harivandi, M.A., K.B. Marcum, and Y. Qian. 2008. Recycled, gray, and saline water irrigation, p. 243-258. In: Beard, J.B. and M.P. Kenna (eds.). Water quality and quantity issues for turfgrasses in urban landscapes: Special Pub. 27. Council for Agricultural Science and Technology, Ames, IA.

Kjelgren, R., L. Rupp, and D. Kilgren. 2000. Water conservation in urban landscapes. HortScience 35:1037-1040.
Levitt, J. 1980. Responses of plants to environmental stresses. Vol. II. Academic Press, New York, NY.

Maas, E.V. 1990. Crop salt tolerance, p. 262-304. In: Tanji, K.K. (ed.). Agricultural salinity assessment and management. ASCE Manuals and Reports on Engineering No. 71, ASCE, New York, NY.

Marcar, N.E. 1987. Salt tolerance in the genus Lolium (ryegrass) during germination and growth. Aust. J. Agr. Res. 38:297-307.

Marcum, K.B. 2006. Use of saline and non-potable water in the turfgrass industry: Constraints and developments. Agr. Water Manage. 80:132146.

Marcum, K.B. and M. Pessarakli. 2006. Salinity tolerance and salt gland excretion efficiency of bermudagrass turf cultivars. Crop Sci. 46:25712574.

Morris, K.N. and R.C. Shearman. 1999. NTEP turfgrass evaluation guidelines. Natl. Turfgrass Evaluation Program, Beltsville, MD.

Pearman, G.I., K. Hennessy, R. Jones, and S. Maheepala. 2003. Climate change and its predicted effects on water resources, p. 174 191. Water, the Australian dilemma. Proc. Annu. Symp. of the Academy of Technological Sciences and Engineering. Acad. Technological Sciences and Engineering, Melbourne, Australia.

Shannon, M.C. 1997. Adaptation of plants to salinity, p. 76-120. In: Sparks, D.L. (ed.). Advances in agronomy. Vol. 60. Academic Press, San Diego, CA.

Steel, R.G.D. and J.H. Torrie. 1980. Principles and procedures of statistics, a biometrical approach. 2nd Ed. McGraw-Hill, New York, NY.

Turgeon, A.J. 2005. Turfgrass management. 7th Ed. Prentice Hall, Englwood Cliffs, NJ.

van Genuchten, M.Th. and G.J. Hoffman. 1984. Analysis of crop salt tolerance data, p. 258 271. In: Shainberg, I. and J. Shalhevet (eds.). Soil salinity under irrigation-Process and management. Springer-Verlag, New York, NY. 